\title{
The role of the firm in worker wage dispersion: an analysis of the Ghanaian manufacturing sector
}

\author{
Somdeep Chatterjee (1)
}

Correspondence: schatterjee2@uh.edu Indian Institute of Management Lucknow, Prabandh Nagar, IIM Road, Lucknow 226013, Uttar Pradesh, India

\begin{abstract}
This paper uses a linked employer-employee dataset from the Ghanaian manufacturing sector to analyze earnings dispersion in Ghana from 1992 to 2003, a period post extensive economic reforms. I find that variance of earnings increased from 1992 to 1998 and decreased thereafter, resembling an inverted u-shaped relationship. I use analysis of variance and variance decomposition approaches to understand the underlying factors that led to such a pattern in earnings inequality. I find that between-firm factors explain this pattern more than within-firm factors. I also find that the mean earnings gap between workers above and below the 90th percentile of income distribution can explain the majority of the initial surge in inequality (61\%) but only explains a very small fraction of the eventual decline ( $9 \%)$. I run OLS regressions similar to Mincerian equations and decompose the variance components to find that the decline in earnings inequality is consistent with decline in variance of firm-level earnings whereas variance of predicted wage from worker characteristics have increased. I also find suggestive evidence of changing patterns of worker-firm sorting which contributes to the decline in inequality. These patterns however only hold up for private domestic firms and not for foreign-owned firms.
\end{abstract}

JEL Codes: J31, O15

Keywords: Wage dispersion, Inequality, Firm effects, Analysis of variance, Variance decomposition

\section{Introduction}

The role of the employing firm in explaining worker wage inequality has been little studied empirically until a very recent paper by Barth et al. (2016). The environment in which a worker is working may have direct and indirect consequences on his eventual earnings through measured or unmeasured channels. The idea of unmeasured worker ability on the one hand and pure industry or firm effects on the other hand are believed to be important factors affecting observed wage dispersion as is documented in the literature on effects of firms on worker wage setting (Dickens and Katz 1987; Davis and Haltiwanger 1991; Abowd et al. 1999; Card et al. 2013a; Card et al. 2013b).

Existing empirical work has shown that separately identifying the effects using longitudinal data is difficult. Hamermesh (2008) points out that the effect would be overstated in favor of the group on which more information is available. So, if information on workers

(c) The Author(s). 2016 Open Access This article is distributed under the terms of the Creative Commons Attribution 4.0 International License (http://creativecommons.org/licenses/by/4.0/), which permits unrestricted use, distribution, and reproduction in any medium, provided you give appropriate credit to the original author(s) and the source, provide a link to the Creative Commons license, and indicate if changes were made. 
is richer than that on firms, the estimated effect of workers would look a lot bigger than that of firms and vice-versa. This is more of a concern if we believe that the worker and firm characteristics are correlated. Hamermesh notes that this is less of a problem if we have a matched employer-employee dataset. In this paper, I use matched data from the Ghanaian manufacturing industry to analyze the role of firms in observed wage dispersion among workers. The empirical methodology of this paper closely follows Barth et al. (2016).

Barth et al. (2016) is, to the best of my knowledge, the only paper that studies the role of establishments in explaining wage inequality using US data. I apply their methodology to study the same question in a developing country setting. I attempt to replicate most of their results in the context of the Ghanaian manufacturing sector. This contributes to the literature as the first paper to study wage dispersion from the perspective of the firm effects in a developing economy. Additionally, I look at how patterns of inequality vary by firm ownership type. Specifically, are private firms owned domestically different from foreign-owned firms? Are the firm effects explaining wage dispersion different based on ownership structure? ${ }^{1}$

In the Ghanaian manufacturing sector, the majority of the firms are in the private sector. ${ }^{2}$ This is largely due to the extensive economic reforms that have been implemented since the mid to late 1980s. An additional contribution of this paper is therefore in terms of analyzing earnings in the post-reform era in Ghana. ${ }^{3}$ I find an unusual and very interesting pattern of wage inequality in the Ghanaian manufacturing sector in this period. In the early periods, the variance in worker earnings increased, but towards the end of the 1990s, the variance in earnings actually decreased. One rather speculative explanation for this could be that reforms were sinking in gradually, and by the time the full effects of the reforms were realized, inequality started to decline. However, while this pattern is true for domestic private firms in Ghana, firms with other types of ownership did not witness this decline in the later periods and they experience a secular increase in variance of earnings. Much of this paper is focused on analyzing this interesting pattern and describing the potential role of the firm component in this.

Although Sandefur (2010) points out that the firm size in the Ghanaian manufacturing sector decreased by almost $50 \%$, this is not necessarily contradictory to the findings of this paper. It has been documented that smaller firms in developing countries are often more productive (De and Nagaraj 2014). This is especially relevant because in the nascent stages, just after reforms have taken place, it may be harder to manage larger firms and gather resources to invest in research and development. Smaller firm sizes may lead to better managed firms with minimal administrative issues and that may lead to a better work environment and establish equity in pay as a result of these efficiency gains. ${ }^{4}$ As I will show later in this paper, the decline in inequality in the Ghanaian setup seems to be driven by the fact that the earnings gap narrows down over time. So even if the idea of firm sizes halving following reforms seem to be perceived as a perverse consequence, with decline in inequality as documented by this paper, the welfare implications of the reforms are not obvious. ${ }^{5}$

Analyzing the variance components, I find that the pattern of inequality observed in the data is explained mainly by fluctuations in the between-firm variation. The within-firm variation has been steadily increasing. The initial rise in variance and the later fall seem to be due to variation between-firms rather than within-firms. It is important to understand 
if this pattern can be explained by gains and losses made by the workers at the top of the earnings distribution. Interestingly, I find that while net gains to workers above the 90th percentile can explain about $61 \%$ of the initial surge in variance, it only explains about $9 \%$ of the later fall. This suggests that workers below the 90th percentile must have made significant gains in the later stages which resulted in closing down of the earnings gap.

I further analyze the interaction of worker and firm characteristics in a regression setting and find that the variance in workers' predicted wage from observable characteristics have increased over time whereas the variance of the firms' effect on wages have declined over time. This pattern is observed for the average firm and on average for firms owned privately by domestic Ghanaians. For foreign-owned firms, however, this is not replicated. The data suggests that the inverted $\mathrm{u}$-shaped pattern of variances of log real hourly earnings for private firms can mostly be explained by a decline in the firm-specific effect at the latter stages. The correlation between the contribution of individual attributes to wages and the firm effect have declined over time. This suggests that firms have gradually hired workers by observable characteristics, independent of firm-specific earnings, or in other words, their preference towards hiring similar workers within a firm has decreased. I find that for high-skilled workers, inequality increases over time whereas it declines for low-skilled workers.

\section{Background}

\subsection{The Ghanaian manufacturing sector}

The Ghanaian economy went through economic reforms from 1983 to 1991. The manufacturing sector was believed to be the engine through which employment generation and long-term economic growth would be attained (see Teal 1998). However, as discussed above, it is unclear as to whether the reforms did more harm than good to the manufacturing sector especially as firms started becoming smaller and literature suggests that smaller firms have lesser potential to grow (see Sandefur 2010). An immediate consequence of providing impetus to the manufacturing sector is that demand for skilled labor would rise. This was no different for Ghana particularly because the two most flourishing manufacturing sectors in Ghana were wood products and textiles. Detailed review of the impact of reforms on the Ghanaian economy can be found in Baah-Nuakoh and Teal (1993). The manufacturing sector has contributed consistently to around 8-10\% of the GDP of Ghana ever since the reforms. Even though by standards expected by the reform, this may look like a small number but the sector employs over 250,000 people. ${ }^{6}$ Apart from wood and textiles, food processing, smelting, oil refining, cement, and pharmaceuticals are other important sectors in manufacturing in Ghana. A rising concern for the sector is the influx of cheap goods from other economies like China which have massive comparative advantages in manufacturing. This is not just a concern for the Ghanaian economy but most of the western African nations. A recent study by Szabo (2016) points out the inefficiencies in the manufacturing sector of Ghana. Szabo estimates production functions for the manufacturing firms and finds that firms mostly use more capital and less labor than the optimal amount.

In this backdrop, it is worthwhile to look at the wage patterns in the Ghanaian manufacturing sector which has been the center of attention for Ghanaian policymakers. It remains indeterminate whether the sector has given the economy the necessary fillip towards economic growth but we can see how much wages have changed over time in 
this sector post the reforms and whether the predominance of private ownership has had significant effects on worker wages or not. Existing research has pointed out that there is a link between economic growth and wage dispersion in African economies (see Agesa et al. 2011 for details in the context of Kenya).

\subsection{Related literature and conceptual framework}

The study of wage dispersion using matched employer-employee datasets has gained popularity in the last decade and a half. Abowd et al. (1999) in their seminal paper introduced the use of a linked employer-employee dataset to run an additively separable fixed effects framework using French data to disentangle the true effect of a firm from that of the worker.

Fafchamps et al. (2009) studied the African manufacturing sector and analyzed the role of sorting in explaining wage gaps. Not much is known however in terms of the role of firms in explaining dispersion in such poor countries. This paper is an attempt to fill this void in the literature. To my knowledge, this is the first paper to use a matched employer-employee dataset to look at wage dispersion by ownership pattern for a developing country. In particular, the idea is to see if private domestic ownership of firms leads to higher or lower wage dispersion as compared to foreign ownership. This paper does not attempt to provide a theoretical explanation as to why wage inequality may differ by ownership type, but the objective is to empirically examine whether such patterns exist in the data.

In the empirical sections of this paper, I run my analyses on two different sub-samples of firms in the Ghanaian manufacturing sector, viz, the private domestic firms and the firms with some foreign ownership. There are many reasons as to why this distinction is of academic interest. First, a body of literature analyzes the impact of FDI inflows on wage dispersion (Saglam and Sayek 2011; Heyman et al. 2011; Almeida 2007 and Martins 2004). The findings generally indicate that foreign firms lead to higher wage dispersion and also pay higher actual wages. One explanation is that foreign-owned firms hire skilled workers and that leads to dispersion. Also, lower skilled workers sort to other firms, and hence, inter- and intra-firm dispersion rises. Second, in what could be regarded as competing theories of the above, several studies suggest that globalization actually leads to reduction in inequality through a decline in wage premium to education in developing countries (see Rama 2002 for a review of this literature). Since the period of study in this paper corresponds to the period post economic reforms in Ghana, it is of interest to check if foreign-owned firms actually differ from private firms in terms of their effects on inequality in worker wages.

\section{Empirical methodology}

\subsection{Analysis of variance}

The empirical strategy I adopt is largely descriptive but provides valuable insight nonetheless. I do a variance decomposition of log real hourly earnings into within-firm and between-firm elements. I follow the method of Barth et al. (2016) throughout this paper and analyze the variance components as follows:

$$
\operatorname{Var}\left(\ln w_{\mathrm{if}}\right)=\operatorname{Var}\left(E \ln w_{\mathrm{if}}\right)+\operatorname{Var}\left(\ln w_{\mathrm{if}}-E \ln w_{\mathrm{if}}\right)
$$

where $\ln w_{\text {if }}$ is the log real hourly earnings (before taxes) for individual ' $i$ ' working at firm ' $\mathrm{f}$ '. $E \ln w_{\text {if }}$ represents the expected value of earnings of workers working at firm ' $f$ '. $\operatorname{Var}\left(E \ln w_{\text {if }}\right)$ is the between-firm variance, and $\operatorname{Var}\left(\ln w_{\text {if }}-E \ln w_{\text {iff }}\right)$ is the within-firm variance. 


\subsection{Percentile analysis: contribution of earnings gap to variance}

Barth et al. (2016) also propose an arithmetic decomposition of the variance in log real earnings to calculate the contribution of the difference in mean earnings for various groups of individuals on the actual variance based on the percentile distribution of earnings. Suppose we want to compare individuals above the $p$ th percentile to those below the $p$ th percentile. Then, if $E(p)$ is the mean of log real hourly earnings of the top $p \%$ and $E(100-p)$ is the mean log real hourly earnings for the remaining workers, then the variance can be decomposed as follows:

$$
\operatorname{Var}(\ln w)=\frac{p}{100} \cdot \frac{100-p}{100} \cdot[E(p)-E(100-p)]^{2}+\frac{p}{100} \cdot \operatorname{Var}(p)+\frac{100-p}{100} \cdot \operatorname{Var}(100-p)
$$

For this paper, I will focus on the earnings gap at the 90th percentile. So the above reduces to

$$
\operatorname{Var}(\ln w)=(0.1) \cdot(0.9) \cdot[E(10)-E(90)]^{2}+(0.1) \cdot \operatorname{Var}(10)+(0.9) \cdot \operatorname{Var}(90)
$$

The contribution of the earnings gap to variances is therefore given by the term $(0.1)$. $(0.9) \cdot[E(10)-E(90)]^{2}$.

\subsection{Worker characteristics and firm fixed effects}

The third and final strategy of this paper is to run OLS regressions for time periods ' $t$ ' as follows:

$$
\ln w_{\text {if }}=\beta . X_{\text {if }}+\delta_{f}+u_{\text {if }}
$$

The vector $X_{\text {if }}$ includes worker characteristics like hours worked, age, age squared, experience, experience squared, education, education squared, potential' experience, and potential experience squared for worker $i$ in firm $f$. Using the methodology described in Barth et al. (2016), I decompose the variance of Eq. 4 as follows:

$$
\operatorname{Var}(\ln w)=\operatorname{Var}(\kappa)+\operatorname{Var}(\delta)+2 \operatorname{cov}(\kappa, \delta)+\operatorname{Var}(u)
$$

In the above, $\kappa=X \cdot \hat{\beta}$ and represents the predicted earnings from observable worker characteristics. The term $\operatorname{Var}(\delta)$ represents the variance of earnings among firms or the variance of the firm fixed effects. Another statistic of interest is the degree of how similar workers are within a given firm, $\rho_{\delta}=\frac{\operatorname{cov}(\kappa, \delta)}{\operatorname{Var}(\kappa)}$. Barth et al. (2016) note that if $\rho_{\delta}$ is close to zero, firms are independently hiring workers based on observed characteristics, independent of firm earnings.

\section{Data}

The dataset for this study is a panel survey of the Ghanaian manufacturing sector which covers the years (waves) 1992 to 2003. The survey was the joint venture of Center for Study of African Economies (CSAE), the University of Oxford, the University of Ghana, Legon and the Ghana Statistical Office for the Regional Project for Enterprise Development (RPED), and Ghana Manufacturing Enterprise Survey (see Data Source Acknowledgment). ${ }^{7}$ The original sample of firms was drawn randomly from the 1987 
census of manufacturing activities of Ghana. From each of the firms, a sample of workers were also interviewed in this period. This allows pooling the two databases to form a comprehensive employer-employee dataset. The original sample had 200 firms in 1992, and firms were added in later waves/years to take care of attrition and other issues. The firms were followed over the years, and therefore, the firm dataset has a panel component whereas the worker component of the data should be regarded as repeated cross sections.

Figure 1 shows the shares of firms by ownership categories from our sample. It appears that the majority of firms are privately owned but some have foreign ownership. For the eventual empirical analysis, I am going to break down the sample into firms owned and managed by private Ghanaian agents, viz, private domestic firms and firms with some foreign ownership. The latter would include firms partially or wholly owned by foreign owners. The remainder of the firms are state owned. Table 1 shows some descriptive statistics from plant-level data. Column (1) reports means for all firms whereas columns (2) and (3) report means for the other two categories. All the means are averages across 12 years of data. Figure 2 gives the time series plots of plant-level averages of some of these observables by ownership types.

The average firm has about 75 workers whereas this number is much smaller for private domestic firms (34) and much higher for foreign-owned firms (194). The number of skilled workers as identified by the firms in their responses to the survey question is 14 on average for the whole sample whereas for private domestic, it is much smaller at around 7 skilled workers per firm. The average education of workers is about 10 years across firm types. Foreign-owned firms seem to have workers with higher average age and potential experience compared to the overall average. Most foreign-owned firms are located in the capital city of Accra. I also find that foreign firms are more likely to export goods compared to private domestic firms. Value of total output is higher for foreign firms throughout the span of the data. There is not much difference in the hours worked by the average worker in these firms although it is slightly less for foreign-owned firms. Foreign-owned firms also have higher wage bills. In terms of input usage and capital, the

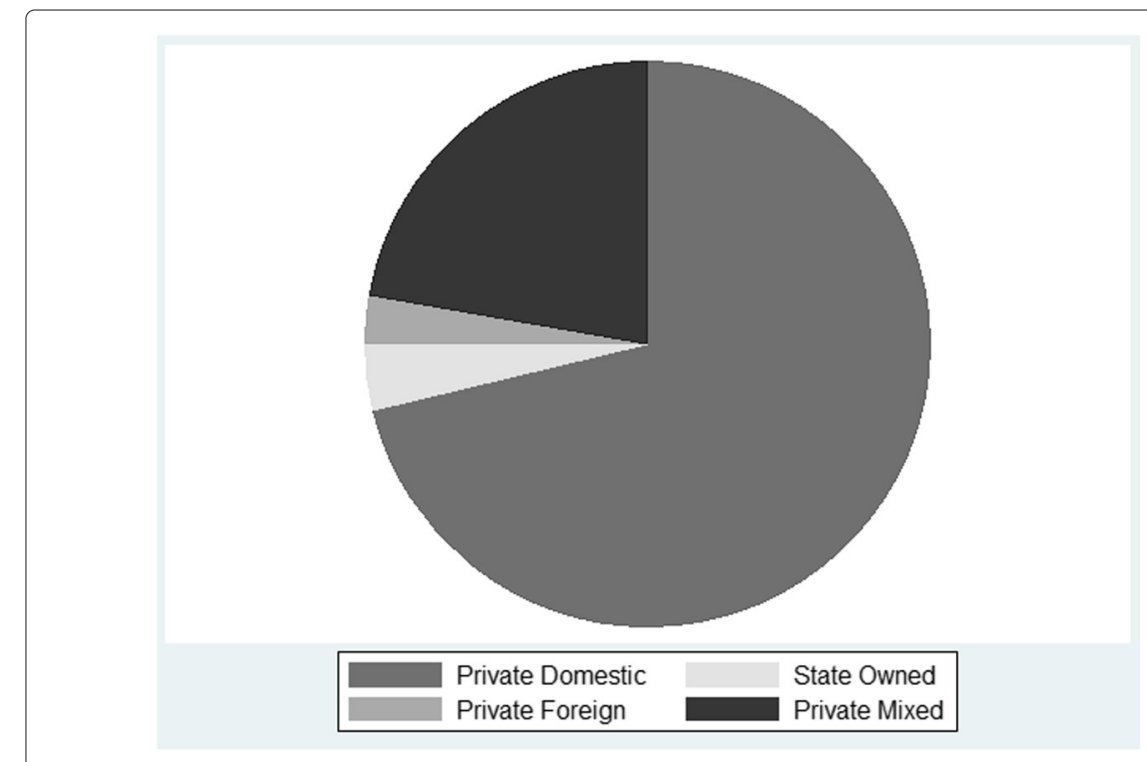

Fig. 1 Share of firms by ownership type 
Table 1 Descriptive statistics

\begin{tabular}{llll}
\hline & All firms & Private domestic & Any foreign \\
& $(1)$ & $(2)$ & $(3)$ \\
\hline Number of workers & 74.50 & 34.53 & 194.41 \\
Number of skilled workers & 13.69 & 6.85 & 35.01 \\
Years of education of average worker & 10.02 & 9.65 & 10.99 \\
Potential experience of average worker & 15.26 & 6.85 & 35.01 \\
Age of average worker (in years) & 32.60 & 30.11 & 39.32 \\
Weekly hours worked by average worker & 45.90 & 46.87 & 43.56 \\
Located in Accra (= 1 if yes) & 0.59 & 0.53 & 0.70 \\
Log annual wage bills & 16.58 & 15.77 & 18.68 \\
Log real output & 17.36 & 16.69 & 19.41 \\
Exports (=1 if yes) & 0.33 & 0.29 & 0.46 \\
Log replacement value of plants and machinery & 17.67 & 16.65 & 20.80 \\
Percentage of inputs imported & 22.03 & 19.13 & 32.56 \\
Observations (firm $\times$ years) & 2400 & 1464 & 804
\end{tabular}

Notes: Data comes from the CSAE-RPED database as discussed in the data section. Any foreign corresponds to firms partially or wholly owned by foreigners. Private domestic refers to firms owned and managed by private Ghanaian resident entrepreneurs. Total observations are 2400; for private domestic, it is 1464; and for foreign owned, it is 804 . Remaining 132 are observations for state firms. All figures are means computed from plant-level database of 200 firms overall for 12 years

data suggests that on average, $22 \%$ of the inputs are imported. This number is somewhat smaller at under $20 \%$ for private domestic firms but significantly higher at $33 \%$ for foreign-owned firms. In terms of replacement value of plant and machinery, the mean for foreign firms is above the average and that for private domestic is below the average for all firms.

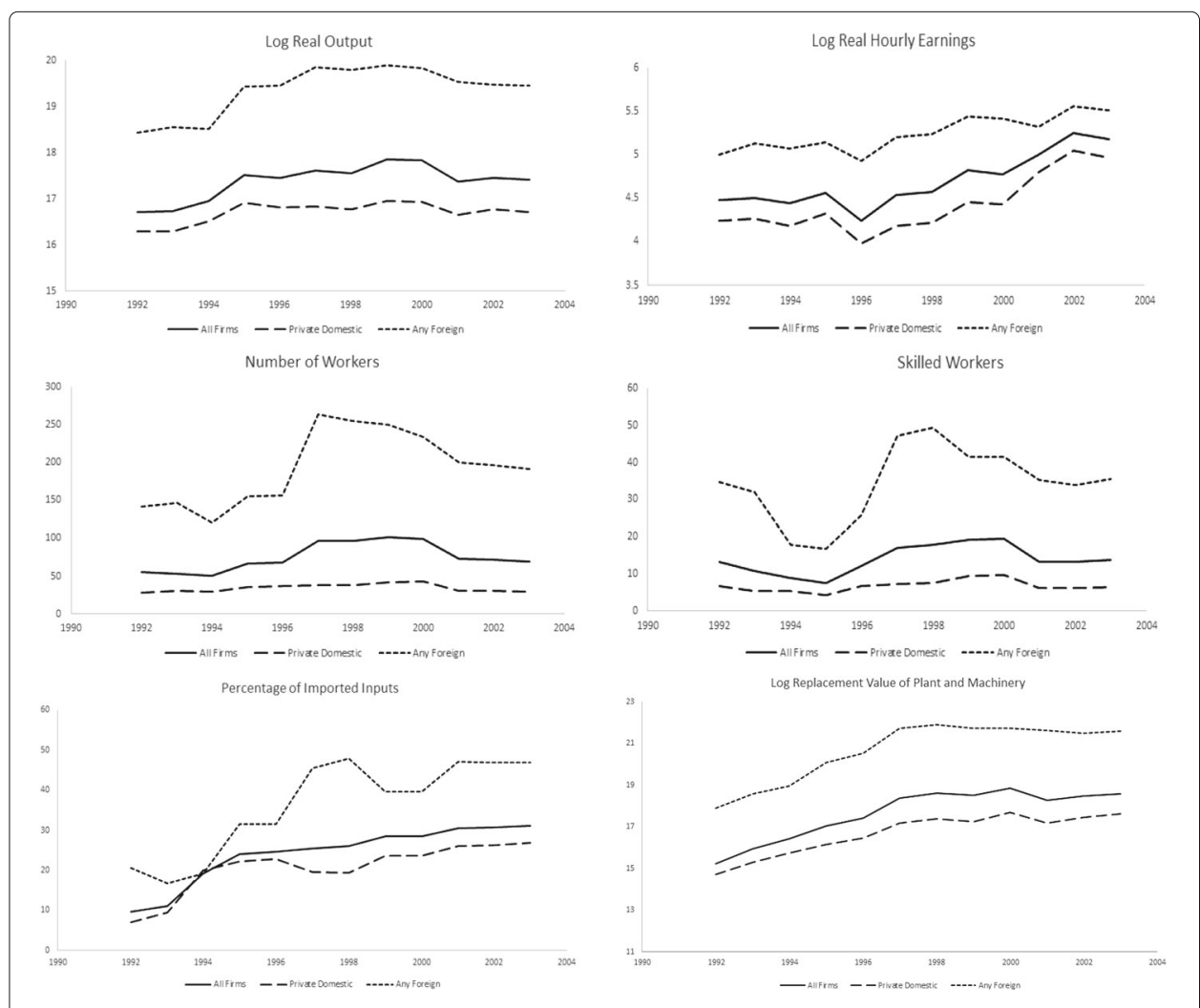

Fig. 2 Time series plots of firm averages by ownership types: firm dataset of 200 firms over 12 years 


\section{Results}

\subsection{Within-firm and between-firm effects}

Figure 3 is indicative of how log real hourly earnings varied in Ghana over the years (1992-2003). ${ }^{8}$ A striking feature of this graph is that the variance of earnings seem to resemble an inverted $\mathrm{u}$-shape for Ghanaian manufacturing firms. The variances seem to have increased from 1992 to around 1998 after which the variances show a decline in trend. This is intriguing because unlike secular increases in earnings inequality which are common in the developed world, including the USA, here, I observe a decline after an initial surge. A possible explanation for this pattern in the Ghanaian manufacturing sector could be the reforms that happened extensively in the late 1980s and continued into the early 1990s. It is plausible that the effects of the reforms on the manufacturing sector, especially for the domestic firms, started accruing around the mid-1990s. This might be the reason that earnings inequality appears to have been checked since 1998 and into the 2000s. A feature of the Ghanaian manufacturing sector was over-staffing. It is believed that post-reform, this has reduced a lot. ${ }^{9}$ This may have also contributed to paying workers more efficiently and a resultant decline in earnings inequality. In Fig. 3, I also look at composition of this variance change for different ownership categories. The Ghanaian manufacturing sector is dominated by private firms. So, I restrict my analysis only to such firms and find that the inverted $u$-shaped pattern is replicated only for domestic firms and not for the partly or wholly foreign-owned firms.

The rest of this paper delves deeper into this phenomenon and attempts to analyze the components underlying such patterns of dispersion. The preceding discussion leads us

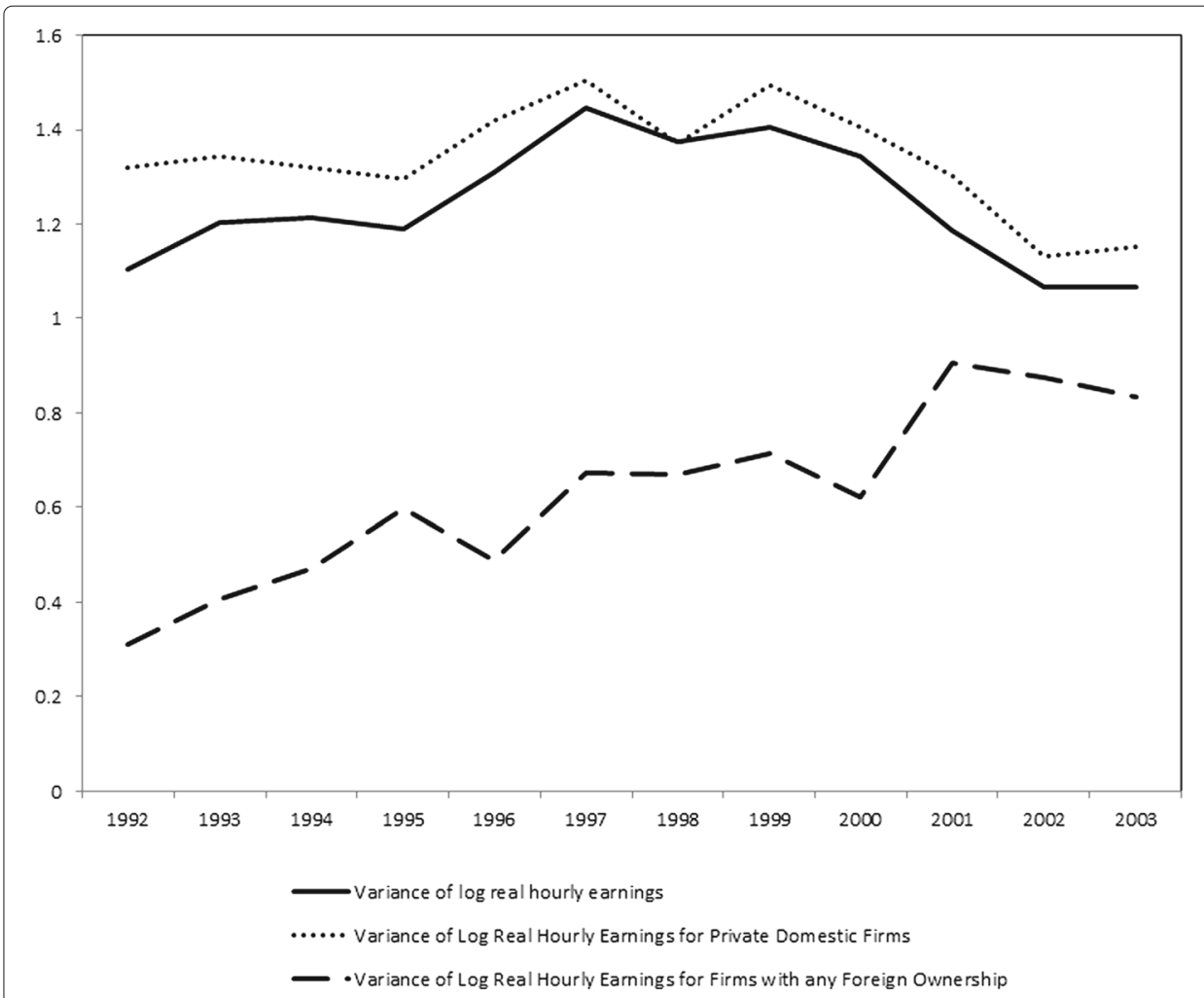

Fig. 3 Variances of log real hourly earnings by ownership type 
into the following question: are these patterns due to within-firm or between-firm variation in worker earnings and how do changes in these components reconcile the overall trends in dispersion? To answer this question, I decompose the variances following Eq. 1. The results are reported in Table 2. I report the total variance of log real hourly earnings along with the within and between components for three different years, viz, 1992, 1998, and 2003, to illustrate how the change in overall variances compare to the change in the within and between components. I find that for all firms, the within-firm variation has increased over time from 0.444 in 1992 to 0.514 in 1998 and 0.748 in 2003. The inverted $\mathrm{u}$-shape of the total variance curve seems to be explained therefore by the betweenfirm component of earnings. It must arithmetically be the case that the between-firm component rises from 0.661 to 0.862 but it falls to 0.319 in the latter half.

Looking at changes over time, I find that the total variance increased in the early period and declined in the latter by a larger magnitude. The change in within-firm variation increased. So what drives this decline is likely to be the change in between-firm variation. It appears that the change in between-firm variance declined from 0.201 to -0.541 .

In Table 3, I analyze the overall variances in earnings by firm type. There are some interesting patterns to note. For private domestic firms, variance seems to be initially flat but declines in the latter period whereas for private foreign firms, it seems to increase in the early period and remain stable in the latter period. If an influx of foreign investment disproportionately attracts skilled labor, this may lead to rising inequality in the other sector, viz, domestic in our case. ${ }^{10}$ Another interesting feature of the economy that this data brings up is the fact that firms with some foreign ownership always have lower inequality than firms domestically owned and managed. This is consistent with the idea that economic reforms may lead to removal of trade barriers, and as a result, foreign firms are now able to hire skilled laborers and unskilled workers sort into private firms based on the firms' comparative advantages. As a result, inequality is a lot lower in levels for foreign firms for whom demand for skilled labor would rise following their comparative advantage in employing skilled workers. This also explains why inequality would decrease overall. Before the reforms, even the high-skilled workers would have had to work in 'inferior' firms due to trade barriers and the absence of foreign firms. These private firms have a comparative disadvantage in employing these high-skilled workers who can move into foreign firms as economic reforms sink in. Again, this hypothesis is not testable with the

Table 2 Analysis of variances of log real hourly earnings of workers

\begin{tabular}{|c|c|c|c|c|c|}
\hline & $\begin{array}{l}1992 \\
(1)\end{array}$ & & $\begin{array}{l}1998 \\
(2)\end{array}$ & & $\begin{array}{l}2003 \\
(3)\end{array}$ \\
\hline \multicolumn{6}{|l|}{ All firms } \\
\hline Total variance & 1.105 & & 1.376 & & 1.067 \\
\hline Within & 0.444 & & 0.514 & & 0.748 \\
\hline Between & 0.661 & & 0.862 & & 0.319 \\
\hline Decomposing the change over time & & 1992-1998 & & 1998-2003 & \\
\hline Total change & & 0.271 & & -0.305 & \\
\hline Within change & & 0.070 & & 0.234 & \\
\hline Between change & & 0.201 & & -0.541 & \\
\hline
\end{tabular}

Data from CSAE-RPED on the Ghanaian manufacturing sector from 1992 to 2003 . I matched the worker and firm files to create the linked dataset based on which I perform the analysis. The arithmetic calculations are based on the method described in Section 3.1 in the text 
Table 3 Variances of log real hourly earnings of workers by ownership type

\begin{tabular}{llll}
\hline & 1992 & 1998 & 2003 \\
\hline Total variance & $(1)$ & $(2)$ & $(3)$ \\
Firms with full domestic ownership & 1.105 & 1.376 & 1.067 \\
Firms with some foreign ownership & 1.321 & 1.343 & 1.147 \\
\hline
\end{tabular}

Data from CSAE-RPED on the Ghanaian manufacturing sector from 1992 to 2003 . I matched the worker and firm files to create the linked dataset based on which I perform the analysis. The arithmetic calculations are based on the method described in Section 3.1 in the text

dataset I am using as there are no pre-reform time period available, so one must be conservative in interpreting the findings in this way. However, the data nonetheless provides suggestive evidence along these lines.

\subsection{Percentile analysis}

Given that we observe the inverted u-shaped pattern for variances in log real hourly earnings, the question of gainers versus losers assumes importance. The purpose of this exercise is to estimate whether gains to the workers at the top of the earnings distribution has contributed to the inequality. For our unique case, this question can be re-framed to accommodate the decline in inequality at the latter stages to see if top earners have lost out on the gains they made or have the rest of the workers caught up. I perform the empirical analysis described in the empirical methodology section above and focus on the decomposition as per Eq. 3. ${ }^{11}$

Table 4 presents the relevant results. I break up the analysis into two periods of time, viz, the surge phase (1992-1998) and the decline phase (1998-2003). In panel A, I analyze the surge phase. Column 2 reports statistics from 1992, column 3 reports statistics from 1998, and column 4 reports the changes from 1992 to 1998. I find that the variance of log real hourly earnings increased by 0.271 log points from 1.105 in 1992 to 1.376 in 1998. I calculate the means of log real hourly earnings for two sets of workers, viz, above the 90th

Table 4 Contribution of earnings gap to variance in earnings

\begin{tabular}{llll}
\hline & $(1)$ & (2) & (3) \\
\hline Panel A & 1992 & 1998 & Change \\
Variance (log real hourly earnings) & 1.105 & 1.376 & 0.271 \\
Mean (log real hourly earnings) above 90th percentile & 5.988 & 6.488 & \\
Mean (log real hourly earnings) below 90th percentile & 4.339 & 4.350 & \\
Difference in means (above-below 90th percentile) & 1.649 & 2.138 & 0.166 \\
Contribution of difference in means to variance & 0.245 & 0.411 & 61.25 \\
Percentage of total change in variance & & & Change \\
Panel B & 1998 & 2003 & -0.309 \\
Variance (log real hourly earnings) & 1.376 & 1.067 & \\
Mean (log real hourly earnings) above 90th percentile & 6.488 & 7.036 & -0.028 \\
Mean (log real hourly earnings) below 90th percentile & 4.350 & 4.974 & 9.06 \\
Difference in means (above-below 90th percentile) & 2.138 & 2.062 & 0.383 \\
Contribution of difference in means to variance & 0.411 & & \\
Percentage of total change in variance & & & \\
\hline Dafrom CSAE-RpeD & & & \\
\hline
\end{tabular}

Data from CSAE-RPED on the Ghanaian manufacturing sector from 1992 to 2003. The contribution of the difference in means has been calculated as per the description in Section 3.2 in the text. The variance in log earnings can be arithmetically decomposed following Barth et al. (2014) as in Eqs. (2) and (3) to calculate the contribution to variance. The percentage share has been calculated as the change in the contribution as a share of the total change in the variance 
percentile and below the 90th percentile. I find that in 1992, the difference in these means was 1.649 and it increased to 2.138 in 1998. Using the expression in Eq. 3, I calculate the contribution of these mean differences to the variance in earnings.

In 1992, the difference in mean log real hourly earnings for workers above and below the 90th percentile contributed $0.245 \log$ points of the total variation of 1.105 . This number increased to 0.411 in 1998. The increased contribution of these differences was 0.166 over the surge period which accounts for $61.25 \%$ of the total increase in variance during this time period. This suggests that the increased advantage of the top earners over the rest had a major contribution to the surge in wage dispersion in Ghana during 1992-1998.

I replicate the above analysis for the decline phase and report the statistics in panel B. Variance in log real hourly earnings declined from 1.376 in 1998 to 1.067 in 2003, a change of $0.309 \log$ points. The difference in means of log real hourly earnings for workers above and below the 90th percentile decreased from 2.138 in 1998 to 2.062 in 2003. The contribution to the overall variance changed by 0.028 which is approximately $9.06 \%$ of the total decline in variance. So the relative advantage of the top earners was not entirely wiped out and was not the major reason why the surge in inequality reversed. This suggests that workers in the rest of the distribution of earnings made significant gains in the latter phases which could probably be attributed to the sinking in of economic reforms.

\subsection{Returns to schooling and earnings dispersion}

I run simple Mincerian regressions as described by Eq. 4 with $X$ denoting the observables like years of schooling, experience, and experience squared only. I use firm fixed effects and run these regressions for two periods of time, 1992-1998 and 1998-2003. OLS estimates of the coefficients are reported in Table 5. I find that the returns to schooling increased over time whereas the marginal effect of experience seems to have declined over time. Variance of the predicted earnings from education and experience has increased from 0.109 to 0.133 . This is not consistent with the fall in variance of earnings over time suggesting that the decline in inequality is explained more by firm factors and residuals and not necessarily by a decline in inequality of returns to schooling and experience.

Table 5 Returns to schooling and experience

\begin{tabular}{lll}
\hline & \multicolumn{2}{c}{ Dep Var: log real hourly earnings } \\
\cline { 2 - 3 } & $1992-1998$ & $1998-2003$ \\
\hline Schooling & $(1)$ & $(2)$ \\
\hline & $\left(0.042^{* * *}\right.$ & $0.063^{* * *}$ \\
Experience & $0.068^{* * *}$ & $(0.002)$ \\
& $(0.012)$ & $0.046^{* * *}$ \\
Experience ${ }^{2}$ & $-0.0013^{* * *}$ & $(0.004)$ \\
& $(0.0003)$ & $-0.0005^{* * *}$ \\
Mean of Dep Var & 4.568 & $(0.0001)$ \\
Variance of Dep Var & 1.460 & 4.654 \\
Variance $(X \cdot \hat{\beta})$ & 0.109 & 1.318 \\
\hline Data from CSAE-RPED on the Ghanaian manufacturing sector from 1992 to 2003. I matched the worker and firm files to create the \\
linked dataset based on which I perform the analysis. Log real hourly earnings are measured in Ghanaian cedis. All regressions \\
include firm fixed effects. Robust standard errors reported in parentheses. *****, and * represent significance at 1,5, and $10 \%$, \\
respectively
\end{tabular}




\subsection{Does predicted wage dispersion by worker and firm characteristics vary by ownership structure?}

This is the final section of the empirical analysis, and I run the regression described by Eq. 4 using many more observable worker characteristics as controls. Since I have identified two distinctive time periods in the data for studying variance in earnings, I break up the analysis in this segment by those time periods. So I run Eq. 4 for the surge period and the decline period separately by pooling together the data from the years in those periods. Using the predicted values of the coefficients from these regressions, I decompose the variance in log real hourly earnings following Eq. 5. For the surge period, I exclude the year 1998 as it is included in the decline period to avoid double counting and maintain distinction between the results of the two periods. Results are reported in Table 6. For the average firm, variance in log real hourly earnings in the surge period was 1.460 and it decreased to 1.318 in the decline period. I decompose the variances following Eq. 5. I find that the variance in predicted wage due to observed worker characteristics increased from $0.235 \log$ points to $0.331 \log$ points whereas the variance from firm-level earnings decreased from $0.595 \log$ points to $0.385 \log$ points. This is consistent with the idea that firm-level characteristics seem to have contributed to the decline in wage inequality in Ghana from 1998 to 2003 rather than worker characteristics. Earlier, I found that between-firm variation seems to explain the inverted $\mathrm{u}$-shaped pattern better than the

Table 6 Variance decomposition: estimated firm effects and predicted wage from worker characteristics

\begin{tabular}{|c|c|c|}
\hline & $\begin{array}{l}\text { Surge in inequality } \\
1992 \text { to <1998 } \\
\text { (1) }\end{array}$ & $\begin{array}{l}\text { Decline in inequality } \\
1998 \text { to } 2003 \\
\text { (2) }\end{array}$ \\
\hline \multicolumn{3}{|l|}{ All firms } \\
\hline Earnings dispersion: $\operatorname{Var}(\ln w)$ & 1.460 & 1.318 \\
\hline Individual characteristics: $\operatorname{Var}(\kappa)$ & 0.235 & 0.331 \\
\hline Firm fixed effect: $\operatorname{Var}(\delta)$ & 0.595 & 0.385 \\
\hline $\operatorname{Cov}(\kappa, \delta)$ & 0.175 & 0.164 \\
\hline Sorting: worker-firm $\rho_{\delta}$ & 0.745 & 0.495 \\
\hline Residuals: $\operatorname{Var}(u)$ & 0.498 & 0.385 \\
\hline \multicolumn{3}{|c|}{ Firms with private domestic ownership } \\
\hline Earnings dispersion: Var(lnw) & 1.551 & 1.369 \\
\hline Individual characteristics: $\operatorname{Var}(\kappa)$ & 0.308 & 0.400 \\
\hline Firm fixed effect: $\operatorname{Var}(\delta)$ & 0.387 & 0.232 \\
\hline $\operatorname{Cov}(\kappa, \delta)$ & 0.124 & 0.081 \\
\hline Sorting: worker-firm $\rho_{\delta}$ & 0.403 & 0.202 \\
\hline Residuals: $\operatorname{Var}(u)$ & 0.580 & 0.535 \\
\hline \multicolumn{3}{|l|}{ Firms with any foreign ownership } \\
\hline Earnings dispersion: Var(Inw) & 0.803 & 0.825 \\
\hline Individual characteristics: $\operatorname{Var}(\kappa)$ & 0.139 & 0.214 \\
\hline Firm fixed effect: $\operatorname{Var}(\delta)$ & 0.134 & 0.441 \\
\hline $\operatorname{Cov}(\kappa, \delta)$ & 0.036 & -0.075 \\
\hline Sorting: worker-firm $\rho_{\delta}$ & 0.259 & -0.350 \\
\hline Residuals: $\operatorname{Var}(u)$ & 0.808 & 1.413 \\
\hline
\end{tabular}

Data from CSAE-RPED on the Ghanaian manufacturing sector from 1992 to 2003. Regressions are extensions of Mincerian equations and include the following independent variables: age, age squared, education, education squared, experience and its squared, and firm fixed effects. Dependent variable is log real hourly earnings, $\boldsymbol{\kappa}$ is predicted wage from observed worker characteristics, $\delta$ is firm effect on earnings, and $\rho_{\delta}$ is the correlation between the worker characteristics and firm effects 
within-firm variation and the findings in this section corroborate those. I find that the variance in the residuals have gone down over time. The sorting factor between worker and firm, $\rho_{\delta}$, also decreased over time. This suggests that with time, firms have employed workers based on observed characteristics and independent of firm-level earnings. This also suggests the possibility that positive sorting was on the decline where higher pay workers now joined lower average earnings firms and that helped bridge the earnings gap and led to a reduction in inequality.

I am interested to know if the patterns for the average firm is universal among ownership types or is it specifically driven by a particular organizational structure. I split the above analysis to separately study private domestic firms and private foreign firms. I find that the average effect is replicated for private domestic firms. The variance of $\kappa$ increased from 0.308 to 0.400 whereas the variance of the firm earnings decreased from 0.387 to 0.232 . The sorting factor also decreased. However, for firms that are partially or wholly owned by foreign private entrepreneurs, I find the opposite. Recall that for these firms, we do not observe the inverted $\mathrm{u}$-shaped pattern in 3 and there is a secular increase in inequality for these firms. The variance of $\kappa$ increased from 0.139 to 0.214 and variance of $\delta$ increased from 0.134 to 0.441 for these firms. This suggests that the ownership structure seems to be an important element that characterizes the unique wage variance structure in Ghana.

\section{Robustness: are these survey-specific trends?}

The major finding of this paper is that there is evidence of decline in worker wage inequality in the Ghanaian manufacturing sector and firm-specific factors in terms of management practices may have played a significant role in this trend. One concern that might arise here is of external validity. The dataset used in this analysis is a small sample of firms from the large manufacturing sector in Ghana. Is it possible that these trends are just specific to this sample and may not be true for the economy overall? Additionally, Sandefur (2010) shows that this particular panel of firms becomes increasingly unrepresentative of the overall manufacturing sector and the Ghanaian economy at large over time. One would be worried that the results of this paper may be driven by the nature of the sample. To check for this and alleviate such concerns, I use three rounds of the Ghana Living Standards Survey (GLSS) -3, 4, and 5 conducted in 1991, 1998, and 2005, respectively. The timelines roughly correspond to the surge and decline periods identified in this paper as above.

I use the data from the Ghana Standard of Living Survey (rounds 3-5) provided by the World Bank as part of the World Bank SHIP database. Using data from the labor/employment file for each of these rounds, I construct a log hourly wages variable as follows. First, I consider their last wage received from their primary jobs, given that the observation corresponds to employment in the manufacturing sector. I disregard observations for employent in non-manufacturing sectors. Then, I use information on the units of this observation to convert it to weekly wages. Finally, using the number of hours actually worked per week, I convert this to hourly wages earned.

The idea is to check if the patterns in inequality using the GLSS household survey data is roughly similar to the findings above. GLSS is conducted by the Ghana Statistical Services and is a household survey. I am unable to replicate the overall analysis of this paper on this dataset as the employing firm of the workers are not identifiable and without a panel of 
firms, the firm-specific fixed effects will not be identified. However, a simple descriptive statistics comparison does provide support to the overall findings of this paper. Results are reported in Table 7.

It is reassuring to find that the trends in the data using the GLSS are similar to the overall trends found using the firm-level linked dataset. I find from Table 7 that the variance in $\log$ hourly wages for workers increased from 1.488 to 1.580 in a period corresponding to the surge period identified in the main analysis above. Also, in the decline in inequality period as identified above, the variance in log wages decrease from 1.580 to 1.306 in the GLSS survey data. These patterns somewhat alleviate concerns that the trends picked up in the analysis are due to the nature of the data being used which becomes increasingly unrepresentative of the population. This robustness analysis provides some confidence that the overall picture of the manufacturing sector of Ghana is being reflected in this paper.

\section{Conclusions}

This paper uses a matched employer-employee dataset from the Ghanaian manufacturing sector to analyze earnings dispersion in Ghana from 1992 to 2003. The plot of variances in log real hourly earnings over time indicate two clear periods of surge and decline in inequality in Ghana. I analyze the variances in earnings from 1992 to 1998 when inequality increased and find that within- and between-firm variation increased during this period. From 1998 to 2003, the between-firm variation declined whereas the within-firm variation still increased. This suggests that the fall in inequality in the latter stages was driven by between-firm effects.

I find that the earnings gap between the workers above and below the 90th percentile explains about $61 \%$ of the rise in inequality from 1992 to 1998 but it only explains about $9 \%$ of the fall in inequality from 1998 to 2003 . This is suggestive evidence that top earners did not necessarily lose out their advantage in the latter stages but other workers made significant gains to wipe out this gap.

Variance in the predicted wages from worker characteristics seem to have risen consistently whereas variance from firm-level earnings have decline in the later period. The correlation between the predicted wage by worker characteristics and the firm earnings have also declined. This leads us to believe that changing patterns of sorting could be a possible reason for the decline in earnings inequality in Ghana. Firms appear to have independently hired workers based on their observed traits and even firms with low average earnings attracted hire pay workers. This meant that inequality would be on the decline. These patterns are however only observed in private domestic firms. Foreign-owned firms do not seem to have such effects on earnings variance. Finally, I use household survey data to show that similar overall trends are also observed for a different database which alleviates concerns about external validity of this exercise.

Table 7 Analysis of variances_GLSS household survey data

\begin{tabular}{lllll}
\hline & 1991 & 1998 & 2005 \\
& $(1)$ & & $(2)$ & $(3)$ \\
\hline $\begin{array}{l}\text { Variance in log hourly wages } \\
\text { Change }\end{array}$ & 1.488 & 0.092 & & -0.274 \\
\hline
\end{tabular}

Data from World Bank GLSS SHIP Database rounds 3, 4, and 5. Variance in log hourly earnings is a constructed variable as described in Section 6 in the text. Even for a different dataset, an initial increase in variance is observed followed by a later decline 


\section{Endnotes}

${ }^{1}$ In an earlier version, I also analyzed how trends in earnings dispersion differ by worker skills but nothing unusual or interesting is happenning there which merits a place in this paper.

${ }^{2}$ This is true in terms of the dataset I use. Census figures may be different nonetheless.

${ }^{3}$ In doing so, I do not intend to draw conclusions about the success (or lack thereof) of the economic reforms of Ghana. To be able to do a complete evaluation of the reforms, not only would we need some exogenous variation to identify the effects of the reform but also ideally need pre-reform data. In the absence of these, any links drawn to the reform should be regarded as conjecture or suggestive evidence and not estimated empirical evidence.

${ }^{4}$ Teal (2016) however suggests that the shift in Ghana towards smaller firms implies that there is a 'missing middle' in the firm size distribution of Ghana and smaller firms tend to be less productive. However, my analysis in terms of just manufacturing firms does not seem to suggest so, especially if one thinks reduction in inequality is closely associated with an increase in productivity or efficiency.

${ }^{5}$ Future research may be directed towards estimating the welfare gains from the reforms, but this paper does not attempt to evaluate the reforms per se but just study the peculiarity observed in patterns of wage dispersion and analyze the role of firm effects in explaining these patterns.

${ }^{6}$ See Natcomm report on Ghanaian manufacturing sector-http://www.natcomreport. com/ghana/livre/manufacturing.pdf

${ }^{7}$ The survey was financed by the Overseas Development Administration (Department of International Development).

${ }^{8}$ The data comes from the pooled firm and worker dataset and not just plant-level data. The log real hourly earnings are therefore worker's earnings in firms.

${ }^{9}$ See Ackah, Adjasi, and Turkson - http://www.brookings.edu/ /media/Research/ Files/Papers/2014/11/learning-to-compete/L2C_WP18_Ackah-Adjasi-and-Turkson.

pdf?la=en

${ }^{10}$ To investigate this further, I looked at the variances by worker skill and found that the inequality for low-skilled workers has reduced over time consistently. This is indicative of the fact that as skilled workers sort into foreign firms, the unskilled (or low skilled) workers end up in domestic firms and domestic firms have a lower skilled pool to choose from. This may lead to a decline in dispersion for low-skilled workers.

${ }^{11}$ As is the case with the rest of the paper, this analysis draws heavily from the 2016 JOLE paper by Barth et al.

Acknowledgements

I thank Chinhui Juhn, Aimee Chin, Andrew Zuppann, and Willa Friedman for their comments and feedback. I also thank Gergely Ujhelyi for the useful discussion and Andrea Szabo and Francis Teal for the insights on the data and recommending additional resources. I thank the participants at the Brown Bag workshop at the University of Houston for the suggestions. Finally, I would like to thank the editor David Lam and an anonymous referee for their insightful comments and feedback which in my view have helped enrich the quality of this paper.

Responsible editor: David Lam

Authors' information

SC is joining the Business Environment Group at the Indian Institute of Management (IIM) Lucknow as an Assistant Professor beginning December 2016. Prior to joining IIM he was an Assistant Professor in the Department of Economics at FLAME University in Pune, India. He has a PhD in Economics from the University of Houston in the USA. This paper is an updated version of an earlier chapter titled, "Firm Ownership and Wage Dispersion: Evidence from Ghana Using Matched Employer Employee Data" which was part of his doctoral dissertation at the University of Houston. 


\section{Competing interests}

The IZA Journal of Labor \& Development is committed to the IZA Guiding Principles of Research Integrity. The author declares that he has observed these principles.

Received: 17 June 2016 Accepted: 4 October 2016

Published online: 28 November 2016

\section{References}

Abowd JM, Kramarz F, Margolis D (1999) High wage workers and high wage firms. Econometrica 67:251-333

Agesa RU, Agesa J, Dabalen A (2011) Changes in wages, wage inequality and the return to human capital skills in Kenya: 1977-2005. Rev Dev Econ 15:676-688

Almeida R (2007) The labor market effects of foreign owned firms. J Int Econ 72:75-96

Baah-Nuakoh A, Teal F (1993) Economic reform and the manufacturing sector in Ghana. RPED Country Studies Series. http://www.csae.ox.ac.uk/reports/pdfs/rep1993-01.pdf

Barth E, Bryson A, Davis J, Freeman R (2016) It's where you work: increases in earnings dispersion across establishments and individuals in the US. J Labor Econ 34:S67-S97

Card D, Cardoso AR, Kline P (2013a) Bargaining and the gender wage gap: a direct assessment. IZA DP 7592. http://ftp.iza. org/dp7592.pdf

Card D, Heining J, Kline P (2013b) Workplace heterogeneity and the rise of West German wage inequality. Q J Econ 128:967-1015

Data Source Acknowledgement: Regional project on enterprise development \& Ghana manufacturing enterprise survey, rounds I to VII (12 years: 1992-2003)

Davis SJ, Haltiwanger J (1991) Wage dispersion between and withing U.S. manufacturing plants. Brook Pap Econ Act: Microeconomics 2:115-200

De PK, Nagaraj P (2014) Productivity and firm size in India. Small Bus Econ 42:891-907

Dickens WT, Katz LF (1987) Inter-industry wage differences and industry characteristics. In: Kevin K, Leonard J (eds). Unemployment and the, Stucture of Labor Markets. Basil Blackwell, Oxford

Fafchamps M, Soderbom M, Benhassine N (2009) Wage gaps and job sorting in African manufacturing. J Afr Econ 18:824-868

Hamermesh D (2008) Fun with matched firm-employee data: progress and road maps. Labour Econ 15:662-672

Heyman F, Sjoholm F, Tingvall PG (2011) Multinationals, cross-border acquisitions and wage dispersion. Can J Econ 44:627-650

Martins PS (2004) Do foreign firms really pay higher wages? Evidence from different estimators. IZA DP No. 1388. http:// ftp.iza.org/dp1388.pdf

Rama M (2002) Globalization and workers in developing countries. East-West Center Working Paper: Econ WP 041. http:// www.eastwestcenter.org/fileadmin/stored/pdfs/ECONwp041.pdf

Saglam BB, Sayek S (2011) MNEs and wages: the role of productivity spillovers and imperfect labor markets. Econ Model $28: 2736-2742$

Sandefur J (2010) On the evolution of the firm size distribution in an African economy. Working Paper, CSAE - Oxford University. http://www.csae.ox.ac.uk/workingpapers/pdfs/2010-05text.pdf

Szabo A (2016) Measuring firm level inefficiencies in the Ghanaian manufacturing sector. Economic Development and Cultural Change (forthcoming). http://www.uh.edu/ aszabo2/marginal.pdf

Teal F (1998) The Ghanaian manufacturing sector 1991-95: firm growth, productivity and convergence. Working Paper, CSAE, University of Oxford. http://www.csae.ox.ac.uk/workingpapers/pdfs/9817text.PDF

Teal F (2016) Firm size, employment and value-added in African manufacturing firms: why Ghana needs its 1 per cent. Working Paper WPS/2016-07, CSAE - Oxford University. http://www.csae.ox.ac.uk/workingpapers/pdfs/csae-wps2016-07.pdf

\section{Submit your manuscript to a SpringerOpen ${ }^{\odot}$ journal and benefit from:}

- Convenient online submission

$\checkmark$ Rigorous peer review

- Immediate publication on acceptance

- Open access: articles freely available online

- High visibility within the field

- Retaining the copyright to your article

Submit your next manuscript at $>$ springeropen.com 